\title{
STATUT I KAZNENO PRAVO MAKARSKE S OKOLICOM U HERCEGOVAČKOM SANDŻAKU
}

\author{
Bartul MARUŠIĆ \\ Upravna škola Zagreb \\ Prilaz baruna Filipovića 30 \\ HR - 10000 Zagreb \\ E-pošta: mlmarusi@inet.hr
}

\author{
UDK: 34(497.5 Makarska) (091)"13/14" \\ 352.07(497.5 Makarska)"13/14" \\ Prethodno priopćenje \\ Primljeno: 25. ožujka 2017 \\ Prihvaćeno: 5. travnja 2017
}

\section{Sažetak}

Makarska i njezino Primorje su zajedno sa "samostalnom" Lokvom Rogoznicom i velikim dijelom Poljica u srednjem vijeku potpadali dugo upravi Osmanskoga Carstva, unatoč bilateralnim i višelateralnim ugovorima s Mletačkom Republikom iz 1444., 1561., 1571. i 1646. godine. Rezultat, međutim, nije bila apsolutna turska dominacija nad domaćim pučanstvom i stratifikacijom postojeće uprave. Suprotno i shodno tomu, osim vrhovnoga poreza i ukidanja plemstva, nema traga feudalnom timaru, šerijatskom pravu ili nasilnom islamiziranju i protjerivanju puka u mirnodopsko doba. Te su sve okolnosti pozitivno utjecale ne samo na održanje postojećih javnopravnih odnosa, nego i na pisano uređivanje novih zakonskih i stvarnih normi koje nam otkrivaju hrvatske narodne običaje od prije turske vlasti, a i tijekom nje, kao i položaj "domorodaca" u to "nesamostalno" doba. Najbolji pokazatelj toga jest statut Makarske i Primorja iz 1551. godine, kojeg je donio narod odnosno liga i koji je ostavljen u samostanskom arhivu u Zaostrogu. Rad donosi tekst toga statuta te Rogozničkog iz 1236. godine ne ulazeći u detaljnu analizu ali s uvodnim 
razlaganjem neke pravne i historiografske misli makarskog Primorja u to vrijeme, u korelaciji s drugim teritorijalno ili institucionalno bliskim područjima.

Ključne riječi: Makarska i primorje; Makarski statut 1551.; osmanska vlast u Dalmaciji; statut Lokve Rogoznice iz 1236.; dalmatinske lige i kazneno pravo.

\section{Uvod}

Nedavnim radom u Bogišićevu arhivu na kutiji IV. "naučnog" arhiva pronađena je interesantna informacija. Naime, profesor Miroslav Alačević je prije više od 100 godina obznanio u svome rukopisu Baltazaru Bogišiću podatak "po čuvenju" od fratra Stjepana Zlatovića. ${ }^{1}$ Radi se naime o pronalasku statuta u Zaostrogu kojeg spomenuti povjesničar datira na više mjesta u 1523. godinu. K tome govori i da je bio pisan na narodnom jeziku, bosančicom i stilom koji je sličan i Poljičkom statutu. Nismo pronašli (još) taj statut, ali je postojao međutim onaj iz 1551. koji po cijeloj priči nalikuje na ovaj o kojemu piše Alačević. Iako ne ćemo pokušati analizirati do kraja taj dokument, donijet ćemo uvod i kratko objašnjenje osnovnih pravnih instituta koji se spominju u statutu, odnosno povijesni kontekst u kojem je nastao.

\section{O statutu i nekim javnopravnim okolnostima Dalmacije u prijelazu sa srednjega na novi vijek}

Sam statut nam daje podatke o kaznenim djelima koja se čine podosta blagima u odnosu na neka druga iz drugih statuta, iako je prvenstveni cilj sastavljača bio očito upravo sprječavanje porasta anarhije. A ona se očitovala kod kršenja reda, poput činjenja tipičnih i "manjih" zločinstava, ali ne velikih crimena. Uz grabež djevojke, čedomorstvo i slično, tu se ubraja krađa (koja je bila u svim statutima ${ }^{2}$ i venecijanskom pravu ${ }^{3}$ jedna od najtežih djela s različitim kvalifika-

1 Kutija IV. "naučnog arhiva" u Bogišićevom arhivu u Cavtatu, A IX., str. 4-5, rukopis od 15. 8. 1894.

2 Goran Tomašević et AL., "Pravni položaj okrivljenika u kaznenom postupku dalmatinskih statuta", u: Hrvatski ljetopis za kazneno pravo i praksu, vol. 21, Zagreb, 2014., str. 104.

3 Guido Ruggiero, "Law and punishment in early renaissance Venice", u: The Journal of Criminal Law \& Criminology, vol. 69, No. 2, Venecija, 1978., str. 
cijama; obična, teška krađa, razbojništvo i sl.), psovanje, napad i drugo. Nema ništa rečeno o turskim upravnim ili feudalnim pravnim odnosima, što potvrđuje emancipaciju i autonomiju lokalnoga stanovništva ili barem težnju za njom do određene mjere. Da su zakoni statuta iz 1551. godine vrijedili i prije, barem u običajnom pravu, svjedoči i uvodna odredba koja kaže kako su kapituli statuta "od vika posluživani".

U prvim člancima statuta eksplicirana je organizacija vlasti i nju čine: serdari, kapetani, knezovi, suci i čauši. Zatim slijedi normiranje kaznenih djela: bogohuljenje, uvrjede i napad (prvenstveno na sakralne vrijednosti i svećenstvo, te roditelje i službenike), otimanje djevojke koje je poznato i u praksi iz dokumenata, ${ }^{4}$ psovanje žene "poštene" (od strane drugoga), krađa $^{5}$ (vola) i drugih stvari, šteta u vinogradima i žitu, zabrana mirenja s lopovima, psovačima ili udarateljima i s druge strane zabrana pak ubijanja živine koja se nađe u šteti (što je isto unikatno), ${ }^{6}$ psovanje "čovika" od strane žene, kažnjavanje svjedoka koji ne bi prijavio počinitelja zločina ili krađe, uzdizanje i nepoštivanje odluke zbora (izdaja) ${ }^{7}$ koje je bilo kažnjavano apsolutnom konfiskacijom i mogućim pogubljenjem, činjenje skandala u društvu, "otmica" sira, masla ili vune, te prijestupi kmetova i trgovaca.

Nekoliko riječi o dispozitivnim odredbama i normama. Proglašavanje optuženika "prokletcem" nije bilo strano u to vrijeme i pripadalo

248. Vidi i: Claudia Passarella, "La tortura giudiziaria nella Repubblica di Venezia nei secoli XVI-XVIII", u: Historia et ius, vol. 9, Rim, 2016., paper 10.

4 Poznato je ne samo u makarskom okrugu nego i u Poljicima gdje se 1665. spominje otmica jedne djevojke i ne tako negativan kontekst običaja prstenovanja i okretanja mladenke (u Poljičkom statutu). http://www.magicus.info/alternativci-i-korisnici/preporuci-knjigu-tehniku-alternativca/copor-djece (24. 3. 2017.).

5 U Rogoznici se krađa kažnjavala s konfiskacijom, abrogacijom plemstva te mutilacijom desne ruke ukoliko se radilo o pučaninu a ne plemiću. Dokaz su bila dva svjedoka koja su se morala zakleti "pred vladaocima". Poljički statut (dalje: PS) u čl. 78 pridržava čak kaznu vješanjem kod krađe veće vrijednosti, a pravi razliku između toga je li se radilo o krađi na teritoriju Poljica ili izvan njih.

6 Čl. 12. Rogozničkog statuta (dalje: RS) dopušta ubijanje životinja koje čine štete na obrađenim poljima. I još k tome pridodaje plaćanje štete oštećenom (sa životinjama) i globu općini. Slično ima i Poljički statut u svome čl. 60c. "Svinje koje se nađu u žitu, koje još nije niklo, mogu biti ubijene." (Zakon o svinjama).

7 Statut Rogoznice čl. 15 govori o zabrani ulaska pučanina u Vijeće gdje je kazna bila 200 batina i "sramotni" permanentni egzil. M. Pera s razlogom smatra da je 200 ili 300 udaraca gotovo ravno smrti. U Makarskoj se predviđa maksimalno 100. 
je "društvenoj smrti" (javno žigosanje) slično onoj koja je bila ekvivalentna izgnanstvu (ili izlaganju gradskoj sramoti). Vidimo u čl. 32. Poljičkog statuta (PS) kako "javno proklet i izopćen ne smije živjeti s ostalim ljudima, osim (čeljadi) s kime stanuje. Ne smije biti pokopan s drugim kršćanima". Isto je predviđeno i za javne lihvare i one koji se ne ispovijedaju barem jednom godišnje, a također i za samoubojice. Nasilno otimanje djevojke vidljivo je u čl. 113. Poljičkoga statuta jer se odnosi na kazneno djelo koje je bilo tipično za taj kraj i učestalo. ${ }^{8}$ Otmica djevojke u Primorju se znala događati po nekoliko puta i čak je sam biskup za takvo što predlagao kaznu odlaska u galije. ${ }^{9}$ Navedena je kazna bila popularna mjera, odnosno sankcija za razne oblike "neposluha" i provodila ju je rigorozno sama Venecija. Ali ticala se najtežih djela poput izdaje, ${ }^{10}$ što znači da se otimanje djevojke smatralo jednim od najtežih djela, uz ostala koja su bila mahom kažnjiva samo novčanom kaznom. ${ }^{11}$ Primjer "kazne galija" imamo

8 O naravi otmice ne slažu se do kraja Ivan Grgić i Benedikta Bučan. Prvi govori u svojim radovima o tome kako je umicanje djevojke bilo nešto različito $\mathrm{u}$ odnosu na otmicu, kakva se piše i aludira na današnji pojam otmice. Tu se zapravo radilo o odvođenju djevojke koja je, međutim, dala svoj pristanak ali bez roditeljskoga pristanka (a da se njih ne "aviza", u čl. 11 Makarskoga statuta, a dalje: MS). Ninski statut također u čl. 67 govori upravo o "unesenju", odnosno odvođenju djevojke ili udovice bez volje - očeve ali/ili materine. Da je crkva bila toliko stroga i htjela radikalno kažnjavati, a radilo bi se samo o "običaju" (i kršenju običaja) a ne o klasičnoj otmici, djeluje možda pretenciozno ipak i za nju, pa su prema Bučan to bili mnogo ozbiljniji slučajevi. Vidi u: JAKšA RAVlić (prir.) Zbornik znanstvenog savjetovanja o Makarskoj i Makarskom primorju 28.-30.rujna 1969., JAZU - Franjo Kluz, Makarska, 1970.; IvAN GRGIĆ, "Statut primorske lige", u: Zadarska revija, god. 4, br. 4, 1955.

9 JAKŠA RAVlić (prir.) Zbornik znanstvenog savjetovanja o Makarskoj i Makarskom primorju 28.-30.rujna 1969., str. 421. Kažnjivo je međutim bilo i "lažno svjedočenje" djevojke kod "umicanja".

10 Izdaja je u Makarskoj bila isto pak najteži prijestup (kazna je smrt), J. RAVLIĆ, nav. dj., str. 345. A i u drugim gradovima i općinama, pa tako i u Lokvi Rogoznici (RS, čl. 18) tko izda Općinu "kamenovat će se", "a njegova dobra imaju pripasti Općini bez ikakva milosrđa". Poljički statut (u izdanju MiroSLAVA Pera, Splitski književni krug, Split, 1988.) predviđao je smrtnu kaznu spaljivanjem kod izdaje Mletačke republike a konfiskaciju, progon i/ili vješanje kod izdaje samih Poljica ili odlaska u borbu zajedno s Turcima (čl. 8, 23a, 23b Poljičkoga statuta). A ono što se u Rogoznici uz to zvalo i "gubitak zvanja plemenitim", to je u Poljicima bio "gubitak zvanja Poljičaninom".

11 "Teške novčane kazne su bile među najtežim kaznama." Isto, str. 422. A od kaznenih djela, čedomorstvo je bilo također veoma sankcionirano, dok je danas to privilegirani oblik ubojstva. 
upravo u odnosu Mlečana i Osmanlija tijekom Kandijskoga rata. Naime, brat glavnog inicijatora pobune Primorjana protiv Osmanlija 1646., kneza "cijelog Primorja" Marka Srdanovića, osuđen je nakon što se pokušao privoliti natrag Turcima nakon neuspjele pobune. ${ }^{12}$

Svako selo je kasnije biralo krvnika, ${ }^{13}$ iako je prema statutu za osudu na smrt trebala odluka Vijeća knezova. Tko se ne bi pokorio naredbama o odlasku na zajedničku obranu grada ili kraja, bio bi kažnjen "strogim vojničkim kaznama" od kojih su dolazili u obzir i rušenje kuće $^{14}$ i osobna kazna "prema prekršaju". 15 "Uz to, opraštaju se svima dosadašnji delikti, kao i onima koji su dosad nerazborito govorili, a stranci koji bi smetali pravilan tijek stvari bit će iz grada i Primorja istjerani. Ubojstvo će biti kažnjeno smrću, izuzevši ubojstva u samoobrani i onakva ako tko uhvati lopova u vlastitoj kući te ga ubije."16 Stoga, ubojstvo se "retributivno" kažnjavalo "istom mjerom" i pripadalo je kaznenim djelima pod kapitalnom sankcijom, a dok je nužna, tu rečeno samo (samo)obrana, oslobađala od optužbe. Također se i ubojstvo u krajnjoj nuždi dopuštalo radi zaštite imovine i posjeda od lopova, što kudikamo podsjeća više na anglosaksonski običaj. Oslobađalo se potpuno od kaznenoga djela (a ne samo kazne) i to bez zahtjeva za ikakvom proporcionalnošću ili postupnošću kakva se danas iziskuje. Jasno, imovina i obrana imovine se u ovom slučaju stavlja kao vrijednije "pravno dobro" čak od života. Spomenuta osuda na smrt u statutu mogla je biti dosuđena, kako je rečeno, od Vijeća knezova i to za (najteže) delikte: uz izdaju $(1,23)$, to su bili i bogohulstvo (8), uvrjeda i tjelesna povrjeda redovnika (8). ${ }^{17}$ To govori

12 Stavko Kovačić, "Iz povijesti župe, sela i kraja...", u: Zov rodnih ognjišta, god. 14., br. 1, Kučiće, 2008., str. 15-44.

13 "...a bit će ovisni o sudcima i krvnicima grada." Jakša Ravlić, Makarska $i$ njeno primorje, Matica hrvatska - Famix, Metković, 2000., str. 91-92.

14 MS u čl. 15. propisuje kako se krivcu ide "na kuću", ali ne iz istog mjesta nego drugog.

15 Tako je bilo u odluci skupštine 1797. (a i u Poljicima npr.). JakšA Ravlić, Makarska i njeno primorje, str. 91. Izdajnik i "odmetnik domovine" bi bio kažnjen time da bi mu se imanje konfisciralo u korist općine. I u statutu se dalje sama izdaja definirala kao: "tko bi reka da neće poslušati skupštinu i zapovid stariji..." (MS, čl. 8), a već u prvom članku stoji da je poštivanje odluka zbora obvezno "pod izgubljenje života".

16 Isto.

17 Članak 5. Rogozničkoga zakona prijeti vrijeđaocu Boga i Djevice Marije kaznom konfiskacijom trećine imanja. Isto predviđa u idućem članku za onoga 
kako su (slično kao ranije u Rogoznici) Crkva i njezine vrijednosti bile (i dalje) primarno zaštićene uz komunalni opstanak. ${ }^{18}$ Tek su u drugom redu delikti inter partes et personam bili zapriječeni i to manjom kaznom. Da je Crkva imala i dalje svoj jak utjecaj, svojim pravom pa i običajem, svjedoči i sankcija "vezivanja kamena oko vrata" (ženi) koja je prilično već nepoznata u okolnim "gradskim" svjetovnim statutima. Činjenica je da su u Makarskoj i Primorju fratri bili najbrojniji i najutjecajniji te ujedno čuvari (i kreatori) pisane riječi i prava, budući da i noviju literaturu o tom području čine prvenstveno radovi i objave iz fratarskih samostana. Roditeljstvo je bilo zaštićeno i zabranjen je napad na roditelje kao i na dostojanstvo starijih, te je kazna isto bila konfiskacija, proglašenje prokletcem ili batinjanje (kumulativno i s novčanom kaznom koja se plaćala općini tj. ligi). U bliskoj Lokvi Rogoznici, točnije reformaciji Rogozničkoga statuta iz 1236., "dizanje ruke" na roditelje bilo je sankcionirano gubitkom sve nasljedne imovine i izgonom iz kuće, s time da se nametala i obveza roditeljima da tako učine i "ništa im ne daju". Napastovanje majke od sina (misli se na incest) kažnjavano je kamenovanjem, kaznom koja je zadržala svoje korijene u Poljicima i Lokvi Rogoznici, dok u Primorju i drugim mjestima nije. Razlika se u Makarskoj ipak činila između batinjanja i šibanja ( $v r u s ̌ t a n j e)$. A mirenje s onim tko čini štetu je uglavnom bilo i zabranjeno $(c ̌ l .18,19)$ dok se za krađu vraćala četverostruka vrijednost stvari umjesto uobičajene dvostruke, kakvu imamo i u Poljicima kada je ratione loci delikta izvan poljičke repu-

tko oskvrne crkvu (uz egzil). Vrijeđanje plemića ili knezova kakvo imamo u članku 10 Makarskoga statuta možemo usporediti s čl. 11 Rogozničkoga statuta gdje se opet uza spomenutu konfiskaciju trećine plodova kumulativno predviđa i tjelesna kazna falange batinjanja, točnije "tabinjanja" u količini od 100 udaraca. Ista je kazna predviđena za isti delikt u makarskom propisu (i gotovo u istom članku). Nadalje, suđenje "po pravdi" iz čl. 11 i 24 Makarskoga statuta vezano za otmicu djevojke ostavlja indikacije o slobodnom izboru sankcije.

18 Makar u tom kraju, budući da je u jeku partikularizma i osobitosti svakoga komunalnoga kraja svaki statut mnoge delikte drugačije kažnjavao. Opširnije u: G. TomašEvić, nav. dj., str. 107. Pa tako i za krađu i bogohuljenje drugi statuti propisuju novčanu kaznu a ne više mutilativnu ili čak smrtnu. Načela slavenskih običaja, rimskog prava i kanonskih odredbi su dakako prednjačila u svojim utjecajima na pisano normiranje. A turski timari i šerijati su zaobiđeni, što je predstavljalo i implicitno odbijanje njihove vjere i vlasti zaključit ćemo. Ali nisu ni Turci to silom nametali u zakone, što čini pravnu i činjeničnu distinkciju kakva nije postajala ni približno u (njima dražoj) venecijanskoj upravi. 
blike ili čak sedmerostruke kao u Vinodolskom zakoniku. ${ }^{19}$ Statut je dakle narodni i pretežno kazneno-pravnoga karaktera, jednako kao i susjedni Rogoznički. Čak i Omiš u svom Omiškom statutu iz 1579. uvodno govori kako je bila potreba da se kodificira pravo koje je i prije postojalo (nepisano). ${ }^{20}$

U sjevernodalmatinskom području dr. Petar Karlić objelodanio je Statut Lige kotara ninskoga ${ }^{21}$ za kojeg je tvrdio da se ubraja među prve statute u Dalmaciji i uopće, jer njegova prvotna verzija datira u prvu godinu nakon Pacte convente 1103., zbog čega se i samog Stipana Ugarskog naziva još "kraljem". Isti statut također sadrži ponajviše kazneno pravo. I to najmanje 70 od 80 kapitula posvećeno je upravo krađi kao krucijalnom deliktu opet. Kazuistički i praktički taksativno nabrojeni su razni oblici krađe i kazni za njih. Kazne su za krađu imovinske, slično kao i za realnu injuriju, a prvi članci odnose se također na organizaciju vlasti koja se sastojala prvenstveno također od kapetana i sudaca. I u ovom je propisu bilo zabranjeno "komodati" odnosno sporazumijevati se s lopovom (ili braniti ga) i dakako obveza je bila "kazati" ga, odnosno prijaviti bezrezervno. Popis običajnoga prava za teritorij između Zadra i Nina iz upravo 1551. i 1553. pak uopće (kako kaže i Bogišić) ne sadrži gotovo ni riječ o kaznenom pravu, pa se ne isplati niti uspoređivati s njim, iako je svaki propis eksplicit određenih običaja iz toga vremena vrijedan pažnje. Dr. Đuro Ljubić ne poklanja ipak puno "vjere" Karlićevoj interpretaciji Ninskoga statuta kao najstarijega, iako ne poriče vrijednost toga spomenika. Dok neki autori (Glavan i Grgić ${ }^{22}$ pa i Lucius te Soldo) o "ligama" govore

19 Marko Kostrenčić (prir.), Vinodolski zakonik, dostupno na repozitoriju: www.pravo.unizg.hr (1.3. 2017.). Ali u njemu je to jedino kod slučajeva kvalificirane krađe dok i u statutu ninskoga kotara vidimo sedmerostruku naknadu štete, ali samo kod "običnih" krađa.

20 Vidi: Antun Cvitanić, "Omiško statutarno uređenje", u: Mosorska vila, br. 3-4, Omiš, 1992.

21 Petar Karlić, "Statut Lige kotara ninskog", u: Vjesnik hrvatskog arhivskog društva, sv. 12, Zagreb, 1912., str. 287-298.

22 "Liga je savez više posoba (sela), a posoba je skup kućnih starješina samog jednog sela, koji su se s vremena na vrijeme sastajali radi izbora sudaca i ostalih seoskih dužnosnika, a raspravljali su o lokalnim, seoskim temama i problemima kao što je imenovanje predstavnika radi zastupanja kolektivnih interesa sela pred vlastima i sudovima, raspodjela radnih i novčanih davanja za potrebe sela, zaštita od kriminalnih radnji itd." Ivan Grgić, "O ligama i posobama. Nekoliko priloga za njihovo proučavanje", u: Zadarska revija, god. 3/1, Zadar, 1954., str. 1. 
uglavnom kao o pojmu normativne skupštine koja je u odnosu na običnu uži pojam i donosi obvezujuće pravne propise, dotle se Ljubić detaljnije pozabavio njihovom genezom na našim i europskim prostorima. On definira lige kao "bratske" zajednice kojima je cilj provoditi kazneno pravo i štititi se. "Ligama i posobama nazivahu se udruženja stanovnika gradskih distrikta, sklopljena svečanim obećanjem ili prisegom u svrhu međusobne pravne zaštite članova i suđenja u njihovim međusobnim sporovima pa održavanja pravne sigurnosti u kotaru."23 Ipak, poslije griješi pišući kako su lige ili posobe postojale samo u sjevernoj Dalmaciji budući da vidimo u ovom predmetnom statutu u Makarskoj i okolici kako se spominje termin liga kao glavni upravni i zakonodavni kolektivni organ (kojem se plaćaju i globe kao javni tereti uz privatne odštete). Piše i o Statutu (lige) zadarskoga kotara iz 1455. gdje se vidi obveza pomoći kod hvatanja napadača ili lopova i solidarna odgovornost. ${ }^{24}$ Postojao je i poklič za tim. Spomenuti statut je ipak mnogo opsežniji od ostalih ovdje spomenutih ali također mu je svrha bila "sprečavanje krađa i razbojštava". ${ }^{25}$ Isto tako je svrha statuta i lige bila i "zaštita pučana od plemićkog nasilja" što u Makarskoj nije slučaj. Naprotiv, i dalje je (u čl. 26) reguliran podređeni položaj kmeta prema gospodaru i njegova poslušnost, iako se već tada pod pojmom "kmet" trebao shvaćati kolon i socijalna razlika nije bila toliko velika niti feudalna. Prigovaralo se Rogozničkom statutu što je intenzivirao pravnu i stvarnu subordiniranost neplemića, a sastavljen je još u doba inkvizicije u 13. st., dok je makarski odnosno primorski Statut puno novijeg datuma. I u Zadru je krađa bila "krovni" delikt jer i sami suci lige, koji su bili na njezinu čelu, nisu mogli obnašati tu funkciju ako su "već bili kažnjeni zbog krađe". ${ }^{26}$ Isto tretiranje onoga tko "zna za krađu", "pristaje" na nju, "skriva" ili

23 Đuro Ljubić, "Lige i posobe u starom hrvatskom pravu i njihov odnos prema Poljičkom statutu", u: Sjednici fil.-jur. razreda JAZU 8.3.1929, dostupno na dizbi.hr (1. 4. 2017.)

24 "Posobe" bi prema Ljubićevoj interpretaciji bile skup više osoba koje hvataju zločinca, dok kod lige svi članovi to čine (liga bi također trebala biti i tijelo koje donosi akte a ne akti koje donosi tijelo). U svakom slučaju i na sjeveru i Primorju oko Makarske cilj je bilo uređivanje lokalnoga reda i borba protiv anarhije bez obzira na vrhovnu vlast viših država, koja i nije bila toliko prisutna u unutarnjem pravu nego je dopuštala i samoupravu.

Đ. LJuBić, nav. dj., str. 45 (1. 4. 2017.).

Isto, str. 47. 
"brani" zločinca ${ }^{27}$ pokazuje sličnost svih triju liških statuta i srednjovjekovnoga pravnog razmišljanja. Općenito je svrha lige i statuta u Zadru bila ipak više preventivna nego represivna, dok u Makarskoj vidimo obje svrhe. Poljička župa je bila osobena, uza zaštitne gilde i konjuracije te razne spomenute lige. U kaznenopravnim ustanovama Poljičkoga statuta vidi se kaznenopravna solidarnost svih članova odnosno Poljičana iako su Poljica puno dalja od sjevernijega Jadrana i drugih krajeva koji pokazuju više sličnosti nego razlike. Zajednička (krvna) osveta zbog rodbinskoga "bratoubilaštva" bila je pokazatelj "bratstva" u (poljičkom) društvu koje s jedne strane nije htjelo do kraja opravdati neke osvetničke čine, pa čak i one u nužnoj obrani, a s druge strane je kompenziralo toleranciju prema takvim činima tako što su vraždu prema obitelji ubijenoga zločinca solidarno snosili i plaćali svi članovi. ${ }^{28}$ No nije u svim mjestima postojala više osveta nego je ona ipak zamijenjena s globom ili samo izbacivanjem, što nije umanjivalo konjuraški karakter svih tih komuna. Korelat osvetama su bile upravo dužnosti kolektivnoga jamstva. I Poljica i npr. Turopolje (pa i Lokva Rogoznica) imali su bratstvo samo što je u prvima ono bilo plod, rekli bismo, umjetnog ujedinjavanja svih bez obzira na stalež, dok je u Turopolju i Lokvi to bila (samo) "bratska adopcija" svih plemenitih stanovnika toga kraja. Stoga zaključno, predmet je to opsežnije diskusije ali je vrijedan početak rada objavljivanje ovih dvaju zaboravljenih manjih ali ne i beznačajnih "statuta" iz priobalnog kraja između Cetine i Neretve.

\section{Rogoznički i Makarski statut/i}

Budući da mnogi stavljaju ipak općinu Lokvu Rogoznicu pod Primorje (tako i Kovačić, ${ }^{29}$ Ante Lulić ${ }^{30}$ i Bjelovučićc ${ }^{31}$ u svojim radovima, kao i neki drugi), objelodanit ćemo i prevesti sa starotalijanskog prvo "novootkriveni" statut Rogoznice iz izvorno 1236., točnije na-

27 Isto, str. 56.

28 Plaćanje vražde kod ubojstva tata koji se zateče in flagranti ili usmrti pri progonu pokazivalo je "primitivni stepen kaznenog prava tada". Isto, str. 97.

29 S. Kovačić, nav. dj.

30 Antonio Lulich, Compendio storico cronologico di Macarsca e del suo litorale, ossia Primorje, Tip. V. Oliveti e Giovannizi, Split, 1860., str. 42-45.

31 Zvonimir Nikola Bjelovučić, "Ugovor makarsko-primorskih knezova s mletačkom republikom god. 1646.", dostupno na: http://dizbi.hazu.hr/ object/8209 (13. 4. 2017.), str. 317-322. 
stavak ili reformaciju istog od godinu dana prije, zatim Makarski ili Primorski statut (MS); oba svojstvena po kratkoći i kaznenom pravu. Položaj žene je vidljiv i sličan u oba statuta i to takav da se prvo uređuju obveze, a zatim i prava žene (ili obrnuto); točnije "prekršaji" koje može počiniti ona i drugi prema njoj. I to pokazuje relativno ravnopravan status žene. ${ }^{32}$ Vinodolski zakon podrobno donosi propise o odnosima među samim ženama i međusobnim uvrjedama, kao i o procesnom položaju žena. Slijede spomenuti dokumenti:

"Drugi zakoni Rogoznice ${ }^{33}$

7. veljače 1236.

\section{U Gorici zvanoj Rogoznica}

Po naredbi sudaca, poštovanih Gospodina Miklos Diklicicha, Vojvode, Radivoja Rubnicha, i Vladimira Blaxevicha, bio je sazvan ovaj poštovani Plemićki Savjet, u kojem su isti Zapovjednici pokazali, da je sve ono što sadrži gore napisani Zakon bilo provedeno i vjerno do kraja izvršeno, što je ovaj Savjet pohvalio i potvrdio, Zapovjednicima su povjereni ključevi Općinske kase i odredili su da pečat Općine treba držati Gospodin Vojvoda, što je utvrđeno i predano mu, kao i da mora neprekidno provoditi prije navedeni Zakon;

Da se niti sin niti kćer ne mogu suprotstaviti vlastitom Ocu, niti vlastitoj Majci, niti podizati ruke na njih, a ako bi to učinili ne bi imali pravo na dio očeve niti majčine imovine, a roditelji ih moraju izbaciti iz Kuće i ništa im ne dati.

Ako sin napastuje Majku, bit će kamenovan ispred cijelog Savjeta.

Ako bi kćer tjelesno zgriješila a Djevica je, u kući svojih Roditelja, bit će sramotno istjerana iz Rogoznice, i nikad se u nju više neće moći vratiti.

32 Silovanje je zapriječeno u gotovo svim statutima, a u Poljicima je kazna za "izbijanje žene bez povoda" bila dvostruka kazna za nasilje (50 libara) dok je za silovanje bila propisana kazna "glavom" i "mrtvom krvlju". Nakon spolnog ataka obveza je bila prvo sklapanje braka s istom, slično kao i u Korčuli (ili Ninu gdje je silovanje bilo razlog da se prvo "uzme" djevojku, a ako su dvojica bila kriva onda je to teretilo prvog "koi e učinia grih", a drugi je plaćao novčanu kaznu - ruho i također globu). Dok je vraćanje ženi udarcima samo za psovke upućene muškarcu bilo zabranjeno i dopušteno je bilo samo tjeranje žene od sebe kod ponavljanja uvrjeda s njezine strane (u Poljičkom statutu, čl. 43).

33 "Prvi" (citirani u radu) su objavljeni u: Miroslav Pera, "Prvi rogoznički zakoni", u: Zbornik radova pravnog fakulteta u Splitu, godina XX.-XXI., Split, 1983.-1984., str. 385 nadalje. 
Onaj koji sa silom obeščasti udatu Ženu, mora se kamenovati ispred Savjeta, a sve njegovo (imovina) pripast će Općini.

Isto će biti učinjeno i onome koji siluje časnu Djevojku; a sva njegova imovina bit će dana istoj za uzdržavanje, i ona će postati jedina gospodarica svega.

Utvrđeno je da su tri od Plemenitaša Nadglednici Zdravlja, i na dan Uznesenja Presvete Marije Djevice moraju izaći iz Savjeta (Vijeća).

Sve to utvrđuje ovaj poštovani Savjet jednoglasno, i naređuje da se zauvijek ovaj Zakon izvršava, a ne može mu se suprotstaviti niti Slavljeni Bog, \& Djevica Marija. Amen.

(Miklos Diklicich Vojvoda,

(Radivoj Rubnich Sudac,

(Vladimiro Blaxevich Sudac,

Pribislavo Vojnich Kancelar Općine Rogoznica kopirao, potpisao i zapečatio,

pravedno u vjeri Statuta." ${ }^{34}$

"Makarski statut lige iz 1551. ${ }^{35}$

Kapituli od zbora hercegovačkoga ${ }^{36}$ koji se imaju opsluživati od svakoga ko prebiva u ovoj krajini ili provinciji i državi, od vika obsluživani, jesu kako slijedi.

34 DrŽAvni Arhiv u Zadru (dalje: DAZD), HR-DAZD-33, Vlada za Dalmaciju, 1802., Stampa delli nobili di Rogosnizza, sv. 167, br. spisa f. 852., str. 264-266.

35 Samostanski arhiv u Zaostrogu (još u uređivanju klasifikacije), spisi na bosančici, nalazi se original. A o statutu, nazvavši ga "primorskim", pisao je ukratko (jedino) Ivan Grgić u: Ivan GrGić, "Statut primorske lige", str. 193 nadalje. A prijepis statuta se nalazio u JAZU, navodno u svesku s natpisom "St. Zlatović, Po listinah bosanicom napisanih u arhivih franovaca Presv. Otkupitelja u Dalmaciji. Prepisi starih listina bosanicom 1464-1780. Kronika Ot.Dubovčanina", pod signaturom I. d. 166 koja je u današnjem HAZU drugačije postavljena.

36 Makarska s primorjem ulazila je tada u "Hercegovački sandžak", pa je i Rogoznica bila de facto u Osmanskom Carstvu kao granično područje prije odnosno poslije Omiša. 
1. Da se imaju stati svi plemići i siromasi, to jest glavari i težaci, i kako odrede to se ima ispuniti, pod izgubljenje života. ${ }^{37}$

2. Da kolikogod ima knezova imaju biti dva serdara, a u svakom serdarluku imadu biti dva kapetana, kako je bilo od vika.

3. Da nemože imati svaki kapetan manje od sto ljudi, i ako bi imao manje i bio bi kapetanom, ne može biti ako mu to zbor ne dopusti.

4. Da se ima učiniti jedan najstariji $\mathrm{knez}^{38}$ koji će biti u svrhu svih.

5. Da na svakih pedeset ljudi se ima učiniti sudac, to jest u svakom kapetanluku dva suca.

6. Da se ima učiniti na svakih 25 ljudi jedan čauš, to jest pod svakim sucem dva čauša.

7. Kada se sve ovo učini kako gore, tada gospoda knezovi imaju dobro promisliti sve što su učinili i našavši sve dobro, imaju potvrditi; ako bi što bilo zlo neka naprave isti gospodski knezovi i što odrede ima se poslušati.

8. Ako bi ko opsovao viru, Boga, Gospu ili učinio kakvu pogrdu u mistu svetom, ili opsova redovnika oliga udario, ima se učiniti skup među braćom i tako ga istirati među braće kao prokletca i uhvatiti i predati knezovima, jer kapetani ne mogu osuditi na smrt, nego samo pokarati.

9. Ako bi koji opsovao Oca ili mater, ima mu se sve porobiti što je njegovo i da mu se udre 100 štapa pak i istira među braćom kao prokletac.

10. Ko bi opsovao starijega, to jest kneza, serdara, kapetana ili koga mu drago poštena starca, ima mu se dati 100 štapa a u ligu groša 25.

11. Ako bi koji ugrabio divojku i ne bi aviza ${ }^{39}$ koga ima, dati pena groša $100 \mathrm{u}$ ligu a njega dati pravdi.

12. Ko bi opsovao ženu poštenu ima dati pena groša 10 u ligu.

13. Ko bi ukra vola, uzmu se četiri za jednoga i dadu se onomu čiji je vol bio; i tako svake ostale živine četvero za jedno a groša 25 u ligu.

14. Ko bi ukra komu dragu stvar, ima se vratiti četverostruko za jedno, a globe kako je robe.

37 Ipak je staleška izjednačenost vidljiva kod općeg zbora gdje se sastaju svi bez obzira kojeg sloja.

38 Slično kao u Poljicima, odnosno negdje kao Veliki knez ili Knez-vojvoda u Rogoznici.

39 Obavijestio. 
15. Kada se nađe krivac u jednomu mistu neimadu mu se slati ljudi na kuću od njegova mista nego od drugoga.

16. Oni čauši koji idu robiti, 'tokaga 10. dio i sve kože od životinje koju se poide, a što se porobi u ligu'.

17. Ko bi potrao žito ili vinograd, 'štima $\mathrm{se}^{40}$ i plati četverostruko.

18. Ko bi pomirio lupeža i ne bi aviza starješine ima mu se uzeti koliko i samom lupežu.

19. Ko bi se pomirio s onim koji bi ga udario ili opsovao i neavizao koga ima, platit će oba jednako.

20. Da nema nitko (pravo) ubiti živo u šteti, nego činiti 'štimati' pak prizvati prid ligu, ter nek mu plati kako je rečeno u kapitulu sedamnaestom.

21. Ako bi žena opsovala čovika, da ima doći na ligu gospodar one žene, i dovesti istu ženu i nosiće kam(en) na vratu i biće 'vruštana' (šibana), a u ligu groša 10.

22. Ako bi ko vidio lupeža ili drugoga zla čovika, a ne bi ga kazao, nego ga (u)taja, upada u istu penu u kojoj bi se našao rečeni krivac i (daje) globe u ligu groša 10.

23. Ako bi se koji uzdiga među zborom, ter bi reka da neće poslušati skupštinu i zapovid starijih damu se imadu poslati ljudi i čauš i sve njegovo živo i mrtvo dovesti na ligu i njega predati knezovima, nevirnika i neskladnika.

24. Ako bi ko našao da ide po sebi u društvo ovdan ili ovnoć čineći skandale i dajući zlu priliku, da se imadu dati u ruke pravdi i u ligu groša 20.

25. Ko bi što oteo komu to jest: sir, maslo, vunu ili kojemu dragu stvar ima se avizati pravda a platiti 10 groša svaki.

26. Ako bi se koji kmet našao koji nepridava pravo svomu gospodaru, ima se gospodar od zemlje dignuti i dati je drugomu, a da mu plati sve što mu je ukra.

27. Ako bi se našao koji čovik da je učinio krivo svomu ortaku u trgovini da i taj plati dvostruko, a u ligu groša 20

28. Ako ne bi platio misniku svoga truda ima se usilovati da plati, a u ligu groša 10 ...

U Zaostrogu, 13.9.1551"

40 Popravlja, usklađuje. 


\section{Statutes and Criminal Law of Makarska and Coast in the Sanjak of Herzegovina}

\section{Summary}

Makarska and its Coast together with Lokva Rogoznica and largely Poljica were in the medieval period for a long time under the rule of the Ottoman Empire, despite bilateral agreements with the Venetian Republic from 1444, 1561, 1571 and 1646. The result, however, was not an absolute domination of Turkey over domestic population and the stratification of the existing administration. In contrast, and consequently, except the supreme tax and the abolition of the nobility, there were no traces of feudal Timaru, Sharia law or a violent expulsion and Islamization of people in the time of peace. All of these circumstances positively influenced not only the maintenance of the already existing public-legal relations, but also the creation of new legal and factual norms, which were described in Croatian folk customs before Turkish rule and during it, as well as the position of the "natives" in this "era of dependence". The best indicator of this is the statutes of Makarska and the Coast from 1551 adopted by a sovereign nation or by the league and preserved in the monastery archives in Zaostrog. The paper presents the statutes without going into a detailed analysis but with an introductory interpretation of some legal and historiographical thoughts of Makarska coastal region at the time, in correlation with other territorially or institutionally related fields.

Keywords: Makarska and the coast; Makarska Statutes 1551; Ottoman rule in Dalmatia; Statutes of Lokva Rogoznica from 1236; Dalmatian league and criminal law. 